\title{
Agriculture versus climate change - A narrow staple-based rural livelihood of Papua New Guinea is a threat to survival under climate change
}

\author{
Patrick S. Michael \\ Department of Agriculture, PNG University of Technology, Papua New Guinea
}

\begin{tabular}{|c|c|}
\hline ARTICLE INFO & ABSTRACT \\
\hline Keywords: & This paper presents a synthesis related to the assessment of climate change and its impacts \\
\hline Climate change & on productivity of staple crops in Papua New Guinea (PNG), paying close attention to the \\
\hline Population increase & change in population in the next 80 years. As much as the changes in the climatic and \\
\hline Rural development & environmental factors will affect agriculture, evidence available in the literature show \\
\hline Staple-based agriculture & $\begin{array}{l}\text { increase in global and local population will put additional pressure on agriculture by } \\
\text { competing with available land and other resources that support agricultural productivity. }\end{array}$ \\
\hline Article history & The developing and underdeveloped countries are considered to be largely vulnerable as \\
\hline Submitted: 2020-05-09 & more than $85 \%$ of the people depend on subsistence agriculture for rural livelihood. This \\
\hline Accepted: 2020-05-28 & $\begin{array}{l}\text { synthesis showed more than } 60-85 \% \text { of the rural people in PNG depend on sweet potato, } \\
\text { banana, Colocasia taro, and greater yam. Projection of the population showed there will } \\
\text { be } 22-31 \text { million people by } 2100 \text { and will depend on narrow staple-based subsistence }\end{array}$ \\
\hline * Corresponding Author & agriculture. The population projected means the density will be 42 people per $\mathrm{km} 2$, putting \\
\hline $\begin{array}{l}\text { Email address: } \\
\text { patrick.michael@pnguot.ac.pg }\end{array}$ & $\begin{array}{l}\text { more pressure on limited land available. When that happens, PNG will not be prepared to } \\
\text { mitigate, be resilient and adapt because of poor infrastructure, no development plans and } \\
\text { lack of post-harvest technologies for loss management of the staples, most of which are } \\
\text { root and tuber crops. }\end{array}$ \\
\hline
\end{tabular}

How to Cite: Michael, P. S. (2020). Agriculture Versus Climate Change - A Narrow staple-based rural livelihood of Papua New Guinea is a threat to survival under climate change. Sains Tanah Journal of Soil Science and Agroclimatology, 17(1): 78-93 (doi: 10.20961/stjssa.v17i1.41545)

\section{Introduction}

Agriculture is the only "practice" on earth that keeps humans alive (Pretty, 1999). The main practices are growing of crops and production of livestock. The productivities of these two practices depend entirely on the input of man (farmers) and the conditions of the environment, e.g. soil nutrient and water and climatic factors (temperature, relative humidity, and $\mathrm{CO}_{2}$ levels) (Costanza et al., 1997; Michael, 2019). Farmers' inputs in agriculture are limited to addressing soil fertility losses, buildup of pests, diseases and weeds, and loss management. The influence of climate and its factors (e.g. temperature, precipitation, $\mathrm{CO}_{2}$ levels, and relative humidity) on crop and livestock production are largely beyond the control of farmers (Gornall et al., 2010). In the light of the current change in global climate, our efforts to understand how agricultural productivity will be affected and the increasing population will be fed, at the local and global scale, are becoming emerging questions for survival of human beings. Globally, change in climate is anticipated to result in higher temperatures, increase in atmospheric $\mathrm{CO}_{2}$ concentrations, and altered precipitation levels (IPCC, 1990), not only affecting agriculture but questioning the "actual survival" of human beings (Battisti \& Naylor, 2009). Because of these, climate change has attracted global attention, making governments, non-government organizations, faith groups, farmers, and even individuals to voice their concerns on collective efforts to address the issues and the impacts (e.g. Thompson, 1975; Nix, 1985).

Recently, Michael (2019) reviewed the current evidence and future projections of climate change and its impacts on critical climate-sensitive areas of PNG. Based on that, this paper addresses how agriculture will feed the increasing population under the future climate and points out critical development needs in agriculture in the rural areas throughout PNG where the mass of the people (>85\%) live. As opposed to plantation agriculture, this study concentrates on production and development of staples since rural livelihood of PNG depends on them. 


\section{Methodology}

Several approaches have been undertaken to complete the entity of the paper. Firstly, a survey of literature on PNG population, climate, and agriculture was done (Michael, 2019). Secondly, the data collected were collated and analyzed to establish: (i) the current and future populations, (ii) the different climates and the agro-climatic zones, and the future climate, and (iii) current staple production and future developmental needs to enable agriculture development in the rural areas to feed the increasing population and help mitigate, become resilient and adapt to climate change. These strategic areas are key to the development of PNG agriculture, economy, food and nutritional security, and wellbeing of the people. The projected time-scales are at an interval of 20 years from between 2020 to 2040, 2040 - 2060, $2060-2080$, and 2080 - 2100, respectively. The demographic data presented are based on four National Census of PNG (1980, 1990, 2000, and 2011) (PNG NSO, 2011). Population count is held every 10 years. The average data from these censuses were used to estimate the 2020 (current) populations and the growth rates.

The projections of future population increases and the associated growth rates were projected using Equation (Eqn.) 1, relative to the 2020 population and growth rates.

$\left[\left(\mathrm{Nt}=\mathbf{P} \times \mathrm{e}^{\mathrm{rt}}\right)\right]$

Where ' $\mathrm{Nt}$ ' is projected number of people in time (t), ' $\mathrm{P}$ ' is current population, ' $\mathrm{e}$ ' is a natural base of logarithms (2.72), ' $r$ ' is the rate of increase (natural increase divided by 100) and ' $\mathrm{t}$ ' is the time period under consideration. A sample calculation for Southern Highlands Province whose average population $(P)$ is 356,013 ; annual population growth rate $(r)$ is $2.8 \%(0.028)$ and time of population increase $(t)$ is 9 years (2011 to 2020) is:

$$
\begin{aligned}
& =\left[(356013) \times\left(2.71828^{0.028 \times 9}\right)\right] \\
& =458,045 \text { people }
\end{aligned}
$$

The current average populations used to project the future populations are shown in brackets $(458,045)$ henceforth. Note, the demographic data and information of Hela and Jiwaka Provinces shown in Figure 1 are not covered as these have just been created and most data for them are not available.

\section{Current and Future Populations}

\subsection{Demographics and current population}

The country (map shown in Figure 1) is the eastern half of the island of New Guinea and lies in the southwest Pacific Ocean, and covers a land area of $462,840 \mathrm{~km}^{2}$. Figure $2 \mathrm{~A}$ shows the changes in population over the last 31 years (1980 - 2011). In 1954, an aerial survey discovered the land was occupied by just under 100000 people. In the last 63 years (1954 - 2017), the population has increased to 8.25 million people (that is $\approx 130,952$ people per year), with 17.8 people per $\mathrm{km}^{2}$ and ranking $167^{\text {th }}$ densely populated in the world. The population was growing at an increasing rate of $20-28 \%$ within this period (Figure 2A). In 2020, the population has risen to 8.95 million (an increase by $92.18 \%$ or at a rate of $1.96 \%$ relative to the 2017 population of 8.25 million people) and ranked $98^{\text {th }}$ in the world.

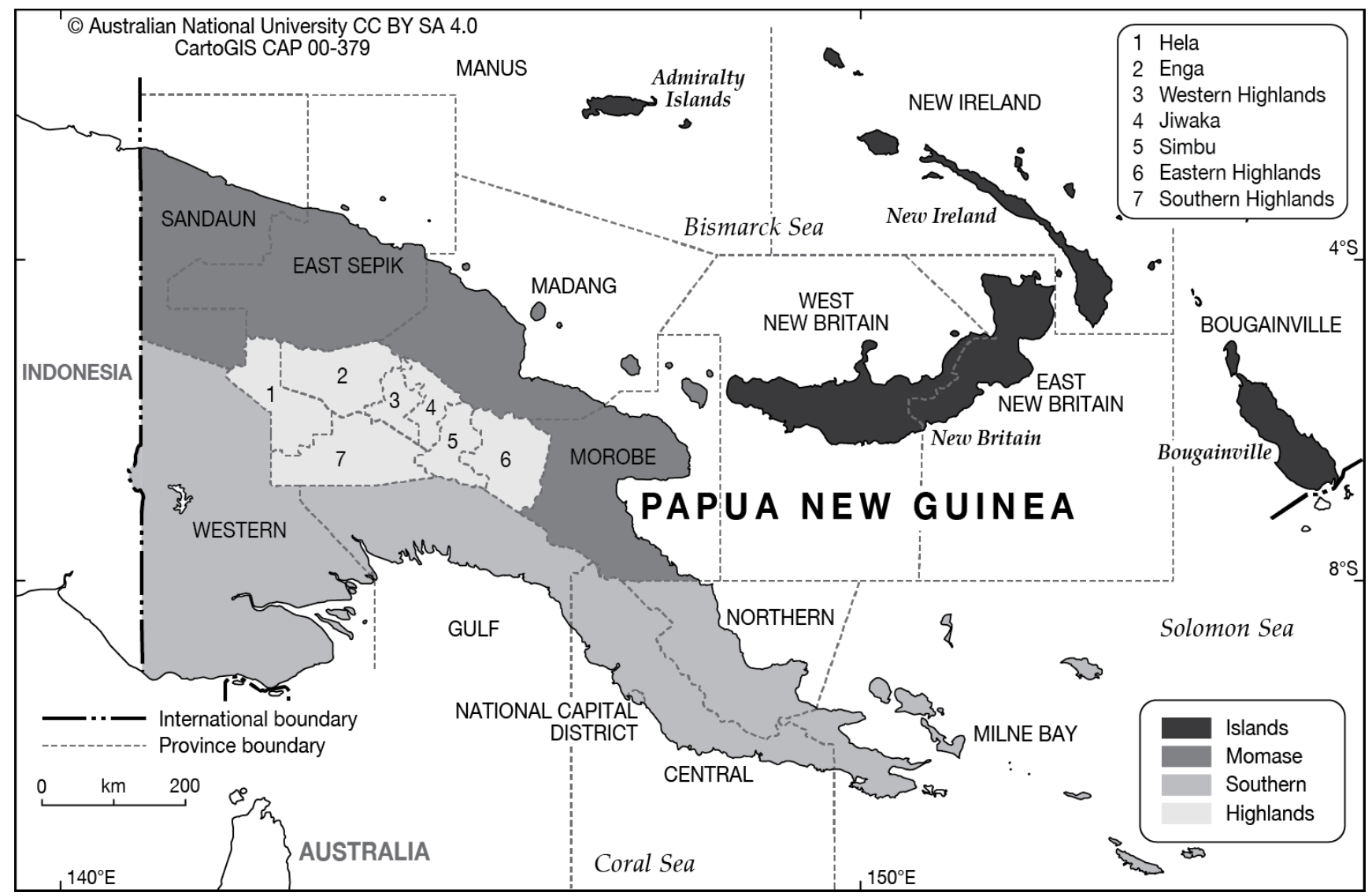

Figure 1. The four regions of PNG (Islands, Momase, Southern and Highlands and their provinces) 


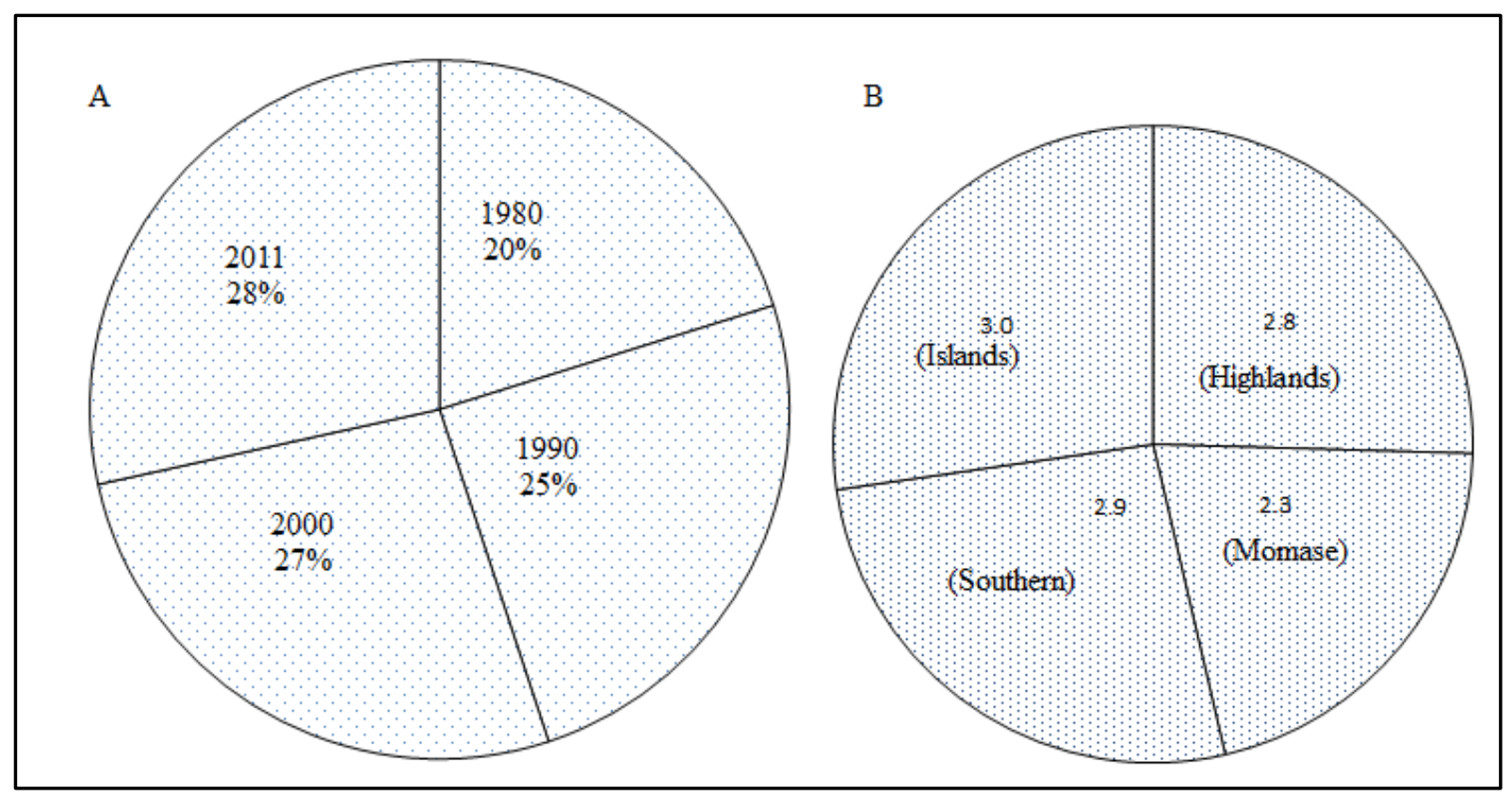

Figure 2. Population growth $(A)$ and growth rate of the four regions $(B)$

The people speak nearly 848 different languages (12\% of the world languages) and make PNG as one of the diverse in the world. Although PNG is one of the fastest-growing economies, nearly $30 \%$ ( 2.5 million) of the people live below the international poverty line of below 1.25 dollars per day and $>85 \%$ live on subsistence-based agriculture alone. Live birth and death per day is estimated to be 647 and 176, respectively, making the net change per day as 466 or 170 , 090 per year.

\subsection{Highlands region}

The Highlands region ( $1500->3500$ altitude) is made up of seven provinces but Hela and Jiwaka Provinces (Figure 1, numbered 1 to 7 in the insert) are not considered for reasons pointed out earlier. The average annual growth rate is $2.8 \%$ (Figure 2B). In 2020, the population of Southern Highlands Province (SHP) is 453,941 (356,013); Enga 379,241 (281,793); Western Highlands Province (WHP) 355,107 $(304,728)$; Simbu $306,031(253,329)$ and Eastern Highlands Province (EHP) $475,945(397,543)$, respectively. This shows population of $\mathrm{EHP}>\mathrm{SHP}>\mathrm{WHP}>$ Enga $>$ Simbu. These data demonstrate that the strongest increase in population growth was in Simbu and EHP, compared to the other two provinces whose populations were already high (Figure 3). On average, nearly 2.4 million (39.25\% of the total) people living in 2020 . That is projected to increase to between 7.0-11.5 million people between 2040-2080. In the next 20 years, which is by 2100, the population in the highlands is projected to increase within a range of 11.5-16.0 million people (Figure 3).

\subsection{Momase region}

Momase region has four provinces (Figure 1). The average annual growth rate is $2.3 \%$ (Figure 2B) and the 2020 estimated population is 1.6 million people (Figure 3 ). That means $587,348(476,238)$ are living in Morobe, Madang $415,412(330,819)$, East Sepik 383,544 $(317,493)$ and West Sepik 222,458 $(179,565)$. Compared to the regional (Momase) growth rate, the 1980 population of all the provinces were high or near high except for East Sepik. The population of the latter province has significantly increased over the last 31 years, nearly equal with the two other provinces except for Morobe, whose growth rate decreased to $2 \%, 0.4 \%$ lower than that of the region. Within the next 40 years (2020-2060), the population of Momase is projected to increase to $3.84-$ 6.04 million people. In the next 40 years, projection indicates the population will be within a range of $6.04-8.24$ million people, respectively.

\subsection{Southern region}

There are six provinces in the Southern region (Figure 1) and their annual average growth rate is $2.9 \%$. In the last nine years relative to 2011, the population of the region has increased to $1,249,314(964,491)$ people of which 179,246 $(135,913)$ are in Western; $124,032(99,488)$ in Gulf; 224,896 $(177,975)$ in Central; 326,034 $(232,119)$ in National Capital District (NCD); 240,594 (193,420) in Milne Bay and 157,250 $(123,327)$ in Northern, respectively. Over the last 31 years, a steady increase in population growth was recorded except for Milne Bay whose growth rate was steady at $2.5 \%$, and the highest was in NCD. Nearly 1.5 million $(7.9 \%$ of the total population) people will be living in this region by 2100 that is $7.9 \%$ of the total population (Figure 3). Between $2020-2080$, the population is projected to increase to $2.7-4.2$ million people and within the next 20 years increase to between $4.2-$ 5.7 million people, respectively.

\subsection{Islands region}

There are five provinces in the Islands (Figure 1) and the region's annual growth rate is $3.0 \%$ (Figure $2 \mathrm{~B}$ ), with the 2020 average population at $938,394(717,641)$ people of which $51,646(40,688)$ are in Manus, $158,443(116,361)$ in New Ireland (NI), 286,039 $(216,790)$ in East New Britain Province (ENBP), 230,453 $(166,976)$ in West New Britain Province (WNBP) and 214,579 $(176,828)$ in Autonomous Region of 
Bougainville (ARB), respectively. The order of population growth over the last nine years was ENBP $>$ WNBP $>A R B>N \mid>M a n u s$. Between 2040 - 2060, the increase in population will be between $2.71-3.35$ million people, and that will increase to between $3.35-4.55$ million people between 2060 - 2100 (Figure 3).

\subsection{Future population projections}

The population projections for the four regions by 2040, 2060, 2080, and 2100 were projected relative to 2020 (Figure 3 ). These data have been used as the background to discuss how agriculture would be developed within the next 80 years to feed the future populations. The regional annual growth rates of the regions have been shown in Figure $2 B$, therefore only the changes in regional population are considered under this section, an important approach to strategize regional agriculture development.

The overall projection showed an increasing population growth between 2020 and 2060 and between 2060 and 2100 and at a slow rate, making the population increase to occur at a steady rate (Figure 3 ). The population in the Highlands could reach nearly $2.43-4.58$ million, Momase $1.61-4.63$ million, Southern 1.21-3.13 million, and the Islands 0.94-2.41 million between 2020 and 2060. These projected increases mean nearly $7.3-8.4$ million people living in 2020 , which will increase steadily to $8.4-12.36$ million in 2040, 12.36-14.75 million in 2060, 14.75-21.77 million in 2080, and 21.77-31.17 million in 2100 (Figure 4). It is quite interesting the stable increase in growth rate in the regions will result in steady population growth from 2060 onwards.

There are a couple of good reasons why the growth rates of the four regions and the overall growth of the population may be decreasing beyond 2080. Two of these are natural increase based on more live births (babies) and fewer babies dying at steady rate because of improved health services, hygiene, and standard of living. Lower positive net migration is third important reason natural changes in population occur.

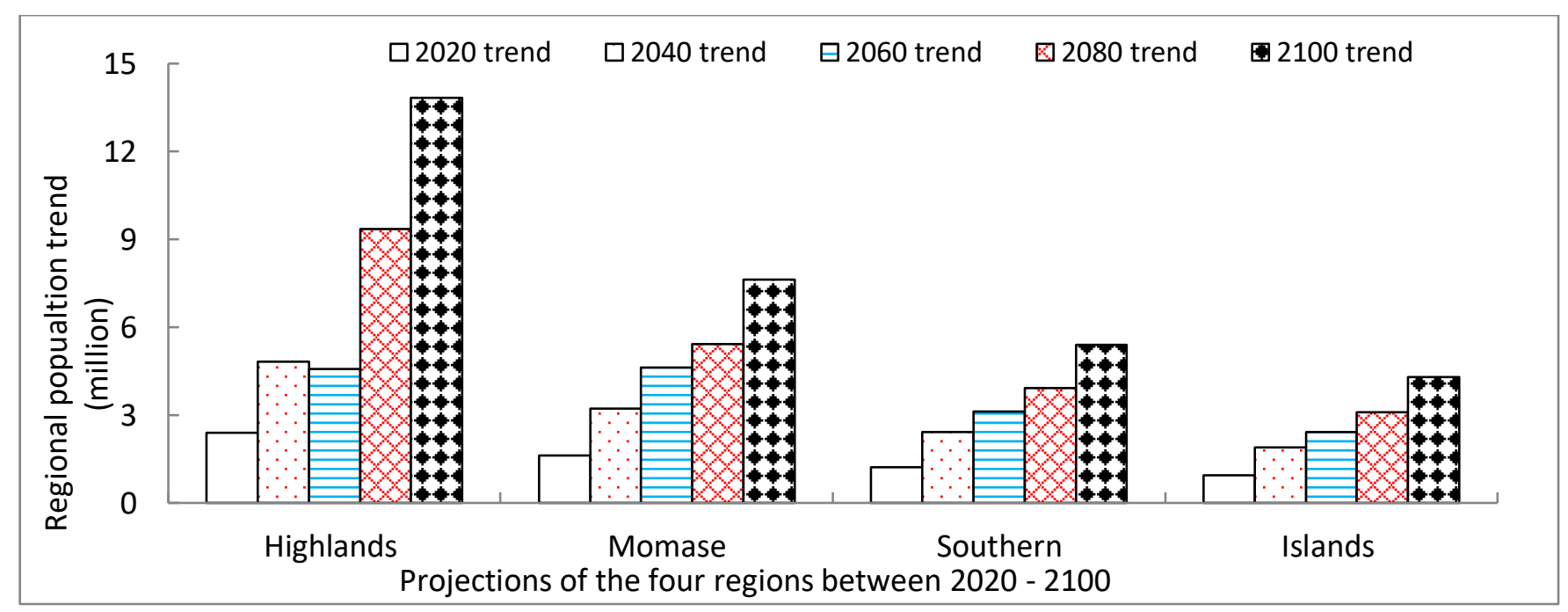

Figure 3. Projection of regional population within the next 80 years relative to 2020 .

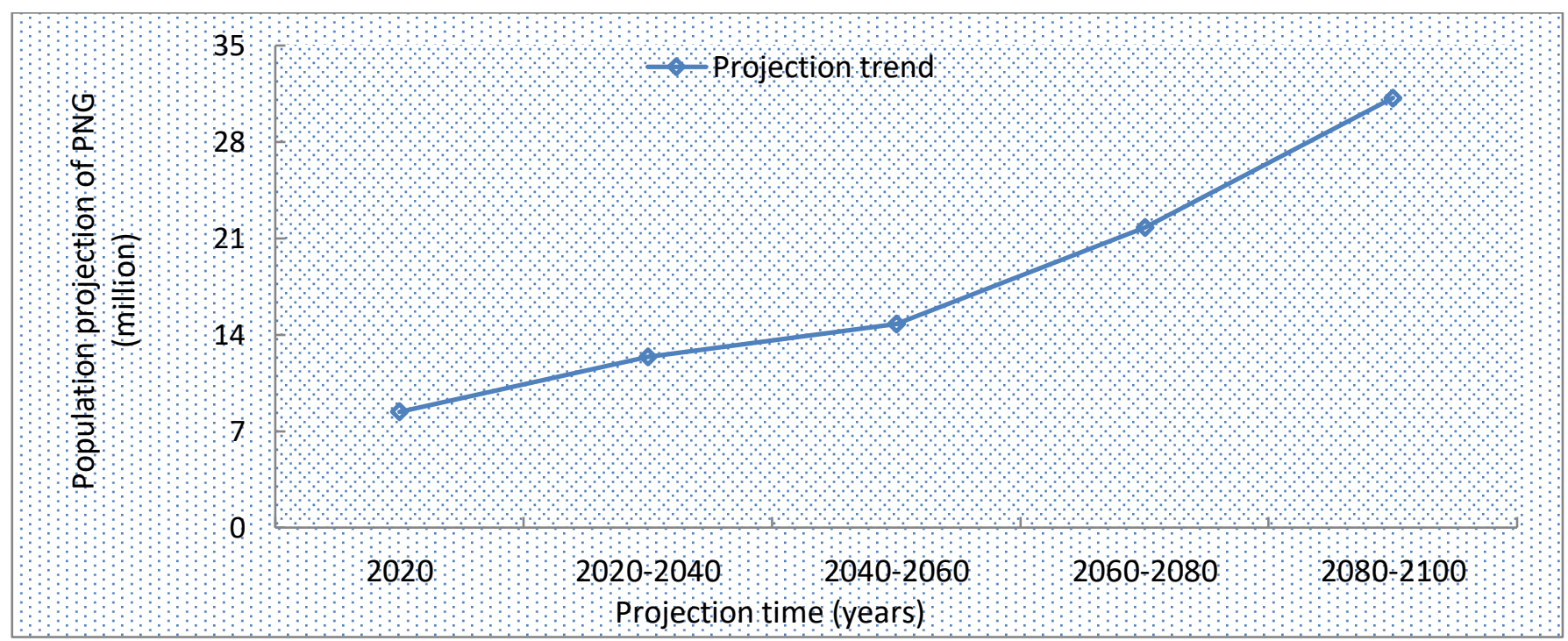

Figure 4. Population projection within the next 80 years relative to 2020 population 
Taking these into consideration, demographers need to establish how the increasing population will live beyond 2040. As the growth rate increases, the population density will increase; say from 19 people per $\mathrm{km}^{2}$ in 2020 to 42 per $\mathrm{km}^{2}$ in 2095 (United Nations, 2019). This is going to present serious challenges as population increases and the climate is projected to change in the same period, and need for human expansion (e.g. infrastructure) and agriculture development (Michael, 2019). In the next section, the current and projected future climate is discussed as climatic and environmental factors affect food production and raise general security issues (health and hygiene, nutrition, and wellbeing, etc.).

\section{Current and Future Climate}

The major classes of climate are shown in Figure 5 . The Equitorial Climate (Af) is characterized by average rainfall of $125-660 \mathrm{~cm}$, the temperature rarely exceeds from within a range of $34-20^{\circ} \mathrm{C}$ and relative humidity ranging from between $77-88 \%$. The Aw climate is mostly found on the Southern coast and is characterized by rainfall ranging from between 260-10 cm during wet and dry season (Peel, Finlayson, \& McMahon, 2007), respectively. The savannahs are (i) Ecalyptus, (ii) Malaleuca, and (iii) mixed. The first is mostly savannah grassland consisting of kangaroo grass (Themeda australis) and cogon grass (Imperata cylindrica), often on drier soil. The second savannah is often flooded and dominated by Cajuputi (Melaleuca cajuputi), tea tree ( $M$. leucadendron), and niaouli ( $M$. viridiflora). These tree species are tough and can withstand periodic inundation, drought, and burning. Under the trees covering the ground are common reeds (Phragmites australis), which is tough and able to vegetate harsh soil conditions (Michael, Fitzpatrick, \& Reid, 2017; Michael \& Reid, 2018). The third savannah is mixed of the two and has a combination of elements from them.

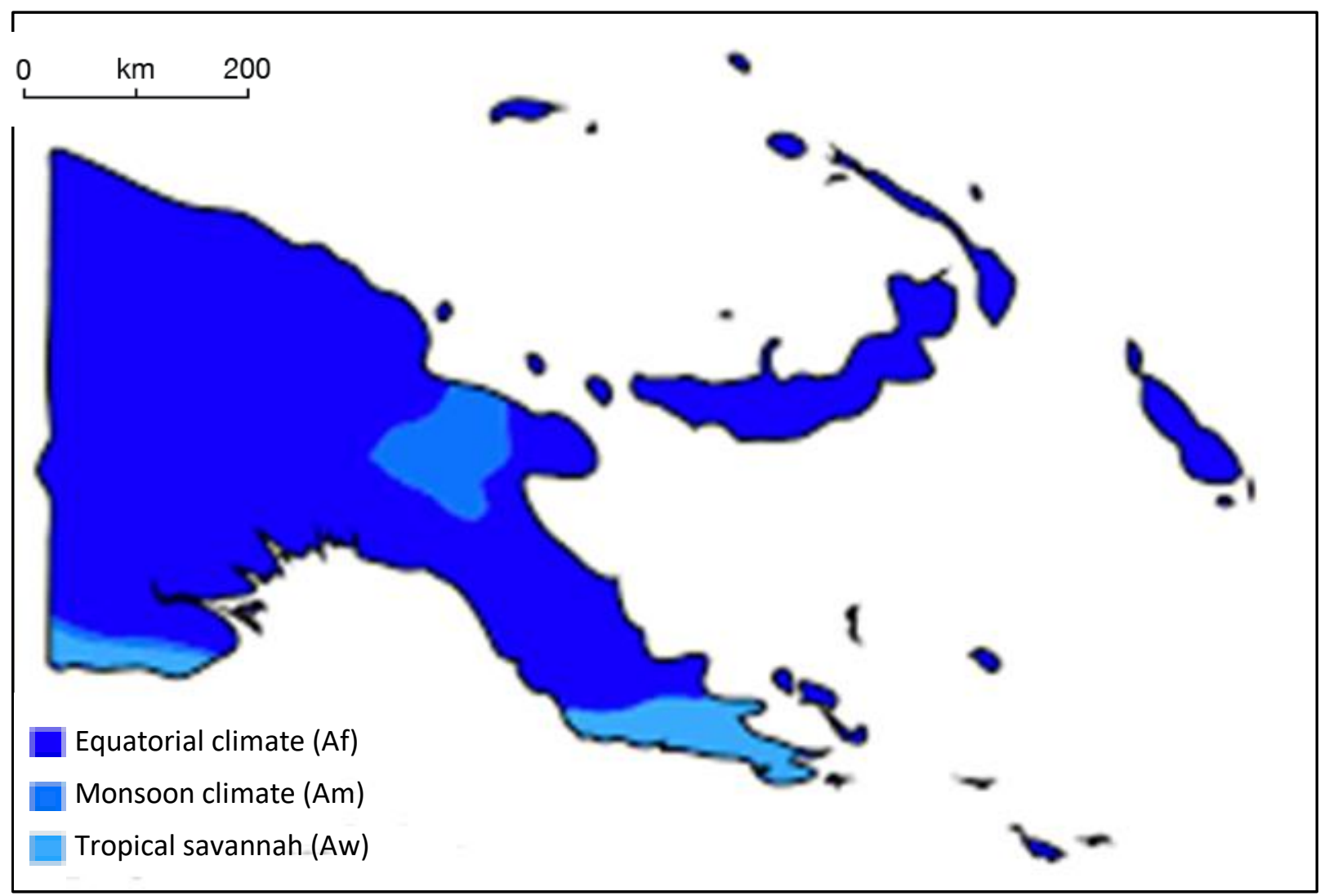

Figure 5. Koppen classification of the main climates (Peel et al., 2007)

Recently, Michael (2019) reviewed the current and future climates of PNG. Continuing that work, the specific climate of the country is considered based on two agro-climatic zones, the highlands and the lowlands (Figure 5). The highlands (high altitude areas) extend from 600 to $>3300$ meters above sea level (throughout referred to as altitude) and the lowlands from 0-600 altitude (Mcalpine, Keig, \& Short, 1975), respectively. The high altitude areas are found along the central range of the mainland and in the islands (WNBP, ENBP, and New Ireland) (Figure 6). The agro-climatic zones based on altitude and annual mean temperature and rainfalls are shown in Table 1. Most areas in PNG receive $200-400 \mathrm{~cm}$ of rain every year with several areas receiving more than 600 $\mathrm{cm}$ of rain, like the provinces in the Islands region and central west of Southern region (Figure 7), with more rainfall between January and April and May and August annually. Places that receive less than $200 \mathrm{~cm}$ of rainfall include northern part of ESP, Markham Valley in Morobe Province, adjacent part of Ramu Valley in Madang, northern part of EHP, southern part of Western Province, the coastline of Central Province, and Cape Vogel-Rabaraba area of Milne Bay Province (Bellamy, 1995). 


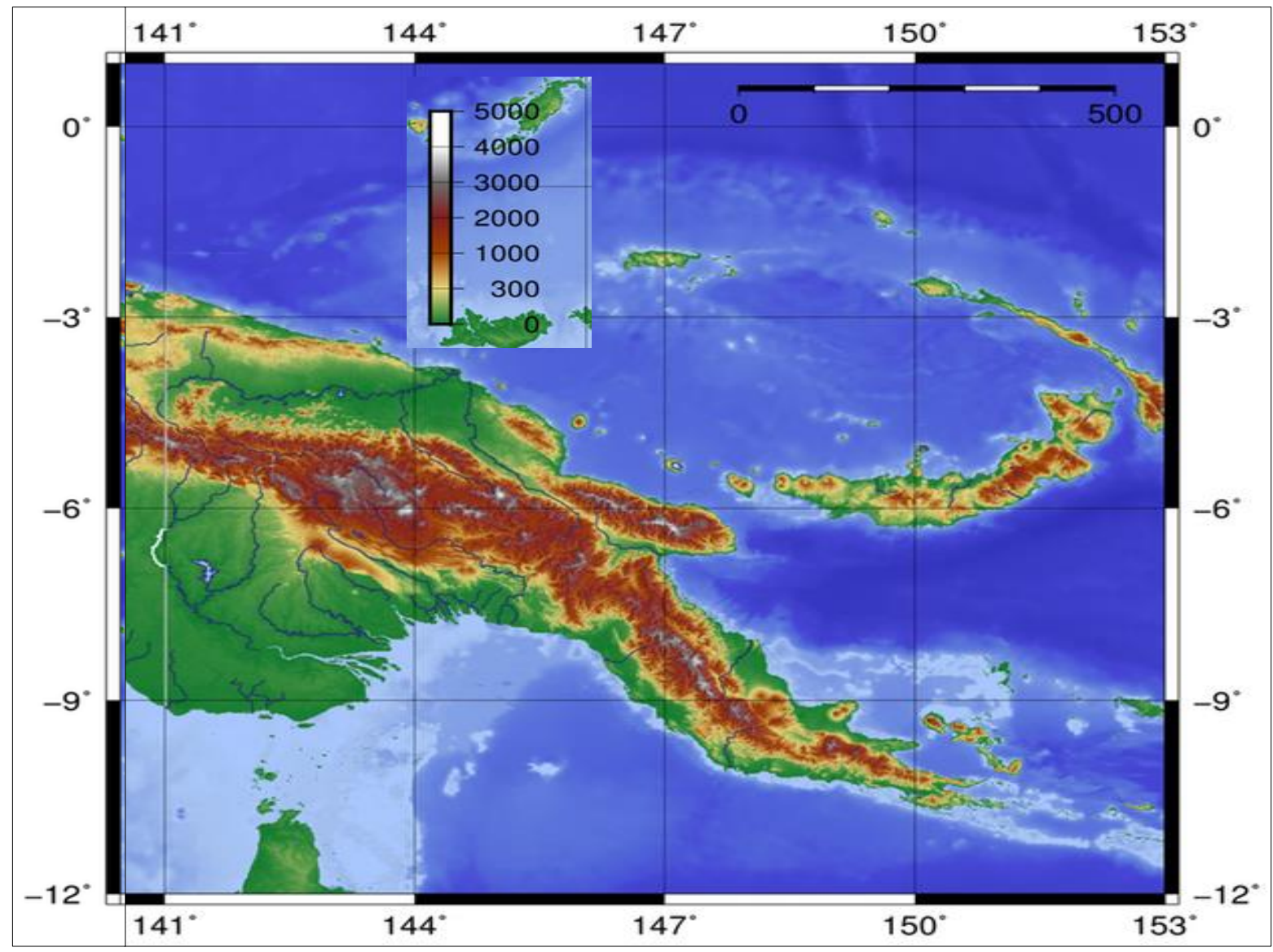

Figure 6. Lowlands are located from $0-600$ and highlands from 600 to $>3300$ altitudes, respectively.

The "lapse rate" is from about 500 altitudes, with every $1000 \mathrm{~m}$ increase in altitude resulting in decrease in temperature by $5^{\circ} \mathrm{C}$. The maximum and minimum differences in temperature caused by the lapse rate are shown in Table 1. These show that rainfall is not affected by changes in altitude but temperature is, with quite high in the central highlands (see Figure 7), the temperature is as low as $4{ }^{\circ} \mathrm{C}$, dominated by alpine forest, and little to no agriculture. In accordance with Table 1, the current extreme temperature is between 28-23 $\pm 4{ }^{\circ} \mathrm{C}$, much warmer in the lowlands and cooler in the mountain and higher altitude areas (Michael, 2019).

As per the regional projections, the maximum and minimum temperatures in the western and eastern half of PNG will change by $0.2-1.4$ and $0.2-1.7^{\circ} \mathrm{C}$ per decade, with the overall change by $0.1{ }^{\circ} \mathrm{C}$ (Michael, 2019). This means that 2020 temperature range is $28.4-29^{\circ} \mathrm{C}$ in the coast, $26.4-27^{\circ} \mathrm{C}$ inland, and $23.4-24{ }^{\circ} \mathrm{C}$ in the mountain areas. In the next 80 years; the temperature is projected to change from between $28.6-29.4^{\circ} \mathrm{C}, 26.4-27.4^{\circ} \mathrm{C}$ and $23.6-24.4^{\circ} \mathrm{C}$ in $2040 ; 28.8-$ $29.6^{\circ} \mathrm{C}, 26.8-27.6^{\circ} \mathrm{C}$ and $23.8-24.6^{\circ} \mathrm{C}$ in $2060 ; 29.0-29.8^{\circ} \mathrm{C}$, $27.0-27.8^{\circ} \mathrm{C}$ and $24.0-24.8^{\circ} \mathrm{C}$ in 2080 , and $29.2-30.0^{\circ} \mathrm{C}, 27.2-$ $28.0^{\circ} \mathrm{C}$ and $24.2-25.0^{\circ} \mathrm{C}$ in 2100 in the coast, inland, and mountain areas, respectively. These projections indicate that the whole country will be warmer by $1.2-2.0^{\circ} \mathrm{C}$ in the next 80 years (2020-2100).

Current projections show most of the places will become wetter; that means that more areas will experience increase in rainfall than the current shown in Figure 7. Most of the places in the Islands region (see Figure 1) will receive 500$1000 \mathrm{~cm}$ and the other three regions $200-500 \mathrm{~cm}$ of rainfall, respectively. The lower and upper central highlands provinces (ranging from 1000-1500 altitude, Table 1) are projected to receive up to $1000 \mathrm{~cm}$ of rainfall annually (Michael, 2019). These could be a problem as too much rain is not suitable for production of most staples under general soil use conditions except for Colocasia taro and sago.

Table 1. Altitude classes associated maximum and minimum temperature and rainfall

\begin{tabular}{llllll}
\hline Altitude $(\mathbf{m})$ & Agro-cliamtic-zone & \multicolumn{2}{l}{ Temperature $\left({ }^{\circ} \mathbf{C}\right)$} & \multicolumn{2}{l}{ Rainfall $(\mathbf{c m})$} \\
\cline { 3 - 6 } & & Maximum & Minimum & Maximum & Minimum \\
\hline $0-600$ & Lowland & 32 & 23 & 1000 & 500 \\
$600-1500$ & Pre-montane & 29 & 18 & $>1000$ & 500 \\
$1500-1800$ & Lower montane & 25 & 13 & $>1000$ & 1000 \\
$1800-2700$ & Mid-montane & 22 & 11 & $>1000$ & 1000 \\
$2700-3300$ & Upper montane & 11 & 4.0 & $>1000$ & 1000 \\
$3300->3300$ & Sub-alpine & $>4$ & 4.0 & $>1000$ & 1000 \\
\hline
\end{tabular}

Source: Bellamy \& McAlpine (1995). 


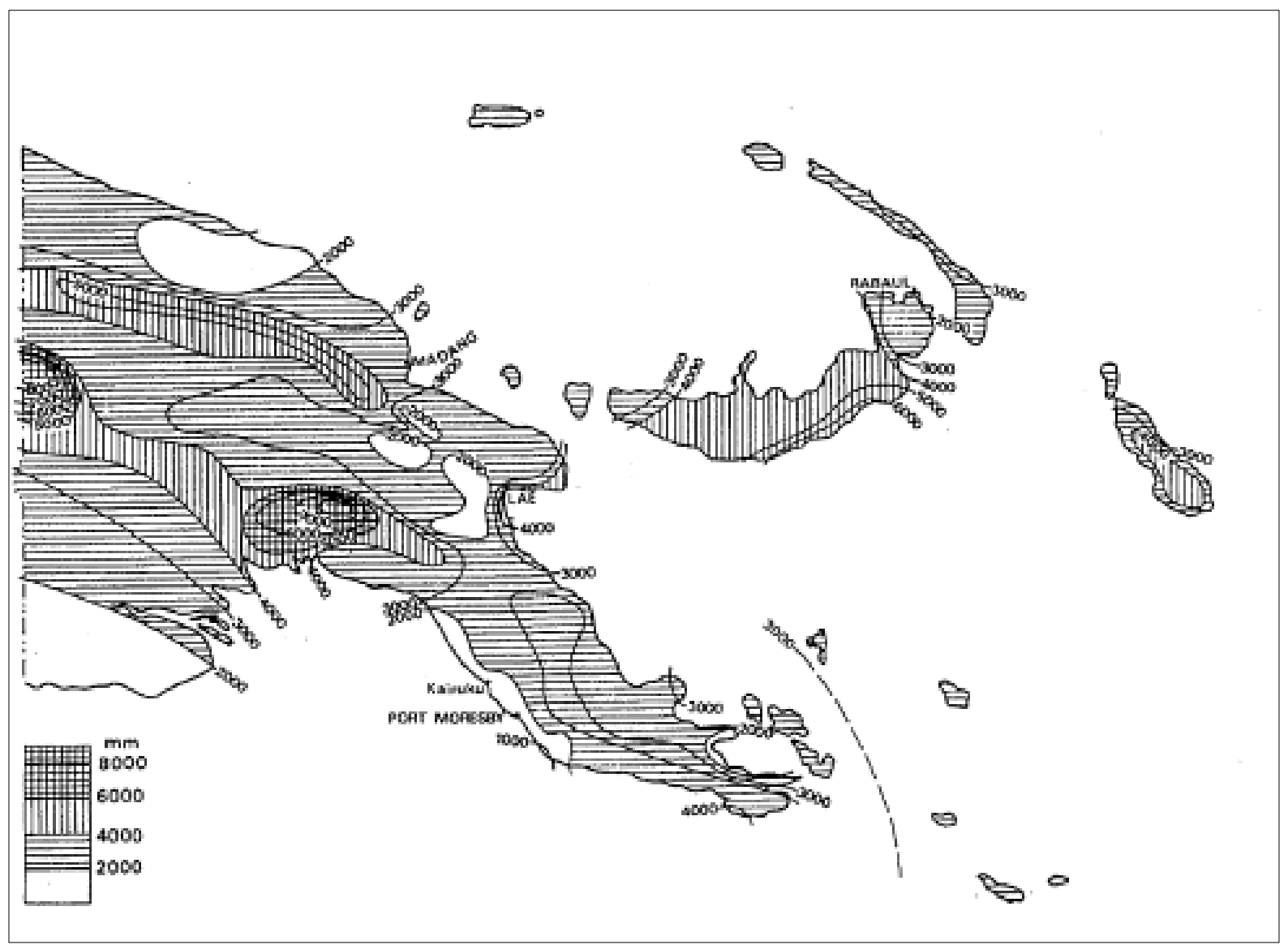

Figure 7. Mean annual rainfall distribution of PNG (Bellamy, 1995).

In rural and peri-urban areas, more than $85 \%$ of the people are subsistence farmers and their livelihood depend entirely on agriculture, necessitating the changes in $\mathrm{CO}_{2}$ level to be discussed. The $\mathrm{CO}_{2}$ levels in PNG over the last 49 years have risen to $1.3 \mathrm{ppm}$ (Knoema, 2018). Taking into consideration the lowest and highest emission scenarios, $\mathrm{CO}_{2}$ levels are projected to increase between 380-1000 ppm (IPCC, 2013). Changes in the atmospheric $\mathrm{CO}_{2}$ concentration are important for production of $\mathrm{C}_{3}$ and $\mathrm{C}_{4}$ plants in subsistence and intensive plantation farming systems. These are further discussed in the next two sections. Increase in $\mathrm{CO}_{2}$ concentration at the moment is not a major concern compared to sea level rise and rising temperature because of the tropical nature of the country having one of the largest rainforest on the planet and a lot of plants needing $\mathrm{CO}_{2}$ for photosynthesis, at least, up to 2040. As climate change takes toll, which plants will survive, will largely depend on the species of plants, either $C_{3}$ or $C_{4}$, as discussed earlier.

It is convincing at least that rainfall is projected to increase and so is $\mathrm{CO}_{2}$ concentration, the terrestrial $\mathrm{C}_{3}$ staples will be on the upper end to benefit from the fertilizing effect of $\mathrm{CO}_{2}$. On the lower end, increase in $\mathrm{CO}_{2}$ means increasing in lowering of ocean $\mathrm{pH}$ because of increase in dissolving of $\mathrm{CO}_{2}$ as rainfall increases. In a tropical nation, home to a diversity of marine life will have imminent impacts on the livelihood of the coastal people. There is already evidence of dead of marine species, seawater intrusion of once dry land, bleaching of coral reefs, saltwater intrusion of freshwater systems and inundation of low lying coastal areas in PNG (Michael, 2019; Sherif \& Singh, 1999; Hussain \& Javadi, 2016;
Lu \& Werner, 2013). The importance is not to stray away from the focus of this study but the concern is that the rural people along the coast grow the staples (Figure 3 ) enough to meet the calorie needs on a daily basis whilst food resources obtained from the sea meet important dietary supplementary requirements, e.g. protein. Loss of fishing or hunting grounds means need for increase in staple production but too late the farmlands would have been already lost to the sea or rendered useless because of high salinity due to saltwater intrusion.

\section{Agriculture Production}

The staples shown in Figure 8 were either domesticated locally or were introduced thousands of years ago. Among the staples shown in Figure 8, banana (Musa sp.), sago (Cycas revoluta), Colocasia taro ( $C$. esculenta), and yam greater (Dioscorea alata) were domesticated in PNG or introduced during ancient times (Bourke \& Allen, 2009). The evidence of production of the staples (agricultural activities) is almost 10,000 years, recorded to be 50,000 years ago. Domestication and expansion of agriculture came at the cost of the environment, depending on the types of technique used and the environment in which agriculture was practiced. Clearing the forest, burning, and drainage were the main ones that impacted the environment the most (Kostrowicki, 1983; Selassie, Anemut, \& Addisu, 2015). Advancement of agriculture due to increase in domestication and introduction of more crops meant loss of soil fertility, buildup of pests and diseases, and introduction of new ones including weeds (Yebo, 2015). Some of the crops domesticated and introduced 
became staples in the last 400 years and feed more than $90 \%$ of the people (Figure 9), today.

Figure 9 shows the total number of people involved in producing the staples. Bourke and Vlassak (2004) estimated the total annual staple production in PNG is 4.5 million tonnes (1050 kg person ${ }^{-1}$ year $\left.^{-1}\right)$. That is a total energy value of $4.3 \mathrm{x}$ 1012 kilocalories ( $2770 \mathrm{kcal}^{\text {person }}{ }^{-1}$ year $^{-1}$ ). Sweet potato (Ipomoea batatas L.) is widely cultivated on subsistence farms from sea level to 2700 altitude under all the major climatic conditions (Figure 5) receiving an annual rainfall of 100-650 $\mathrm{cm}$. Production of this crop is very much well established in all the rural villages (99\% of the people involved in growing it) (Allen, Bourke, \& Hanson, 2001). Fifty to $96 \%$ of the people are involved in growing banana, Colocasia taro, Greater yam, cassava (Manihot esculenta), and Chinese taro (Alocasia cucullata). The number of staples grown by less than $50 \%$ of the population include coconut, sago, lesser yam ( $D$. esculenta), Irish potato, Chinese taro, and a number of other crops (8-<4\%) (Figure 9).

Under the current climate, sweet potato (66\%) feeds more people than sago (11\%), banana (9\%), lesser yam (7\%), Colocasia taro $(6 \%)$, Chinese taro $(3 \%)$ and cassava $(1 \%)$
(Bourke \& Allen, 2009). Most of these crops are grown in combinations of two or more, typical of village mixed farming systems. Within the last 340 years (1660 to 2000), production of Colocasia taro, banana, and yam have dropped from 50 , $22,12 \%$ to $4,8,5 \%$, respectively (Bourke \& Allen, 2009). Even Chinese taro and sago production declined over the same period. The only staple that has become prominent and production has increased from $40 \%$ in the 1880 s to $66 \%$ in 2000 is sweet potato, supporting the widespread distribution of the crop (Figure 8). Sago production was steady in the 1800 s to the 1900 s but in the 2000 s declined to nearly $4 \%$ (Bourke \& Allen, 2009). Analysis showed Colocasia taro was widely consumed in 1600 s prior to introduction of sweet potato in the $1880 \mathrm{~s}$, followed by banana, sago, and yam. A limited number of staple-based agriculture feeding the whole population is risky, in the light of climate change and associated changes in the agro-ecosystem, resulting in incursion of pests and diseases that could be difficult to manage. The basic dependence on a selected staple alone is sufficient evidence to develop the agriculture sector to diversify production and reduce the risks of food insecurity.

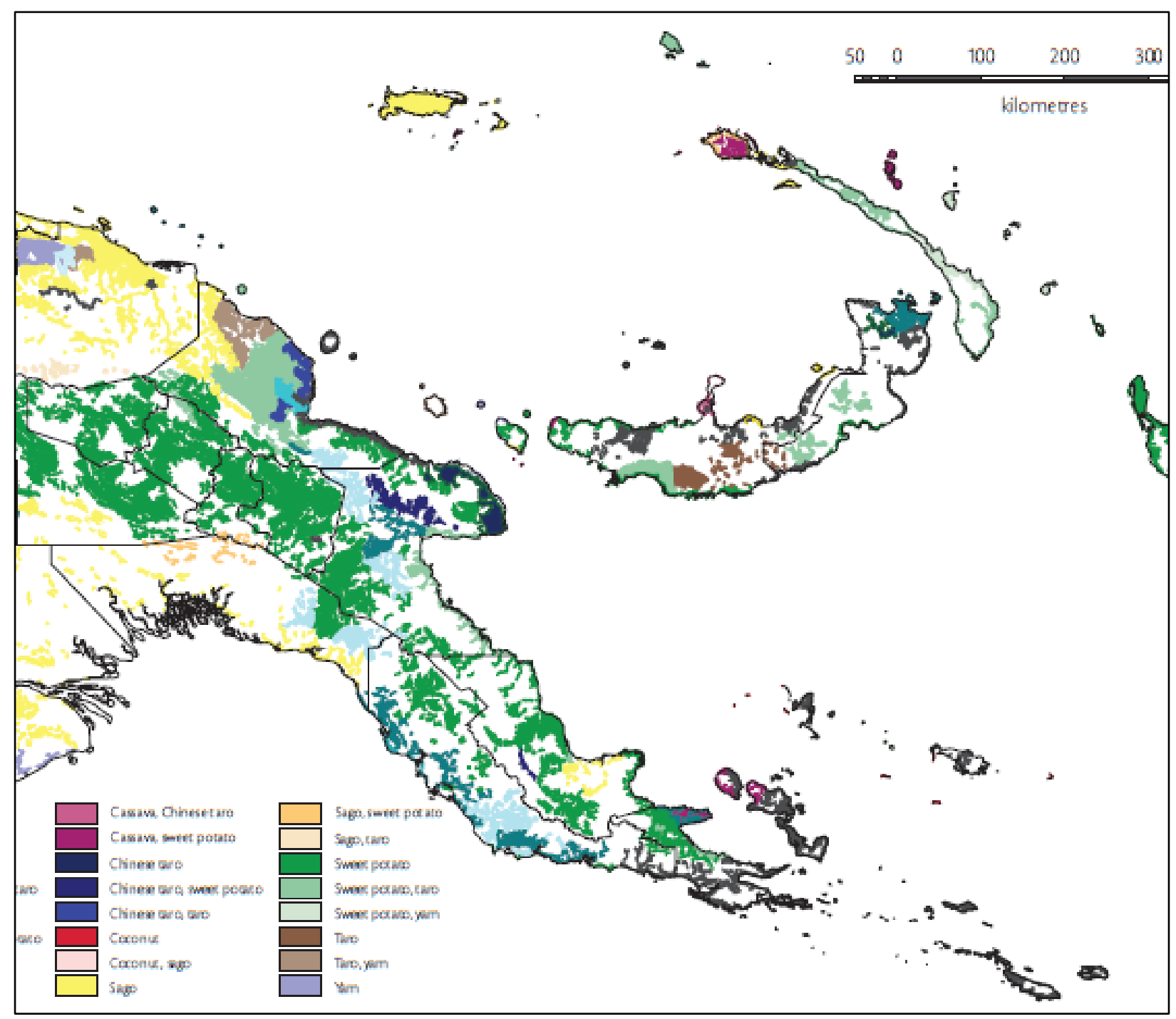

Figure 8. Dominant staples of PNG (Bourke \& Allen, 2009). 


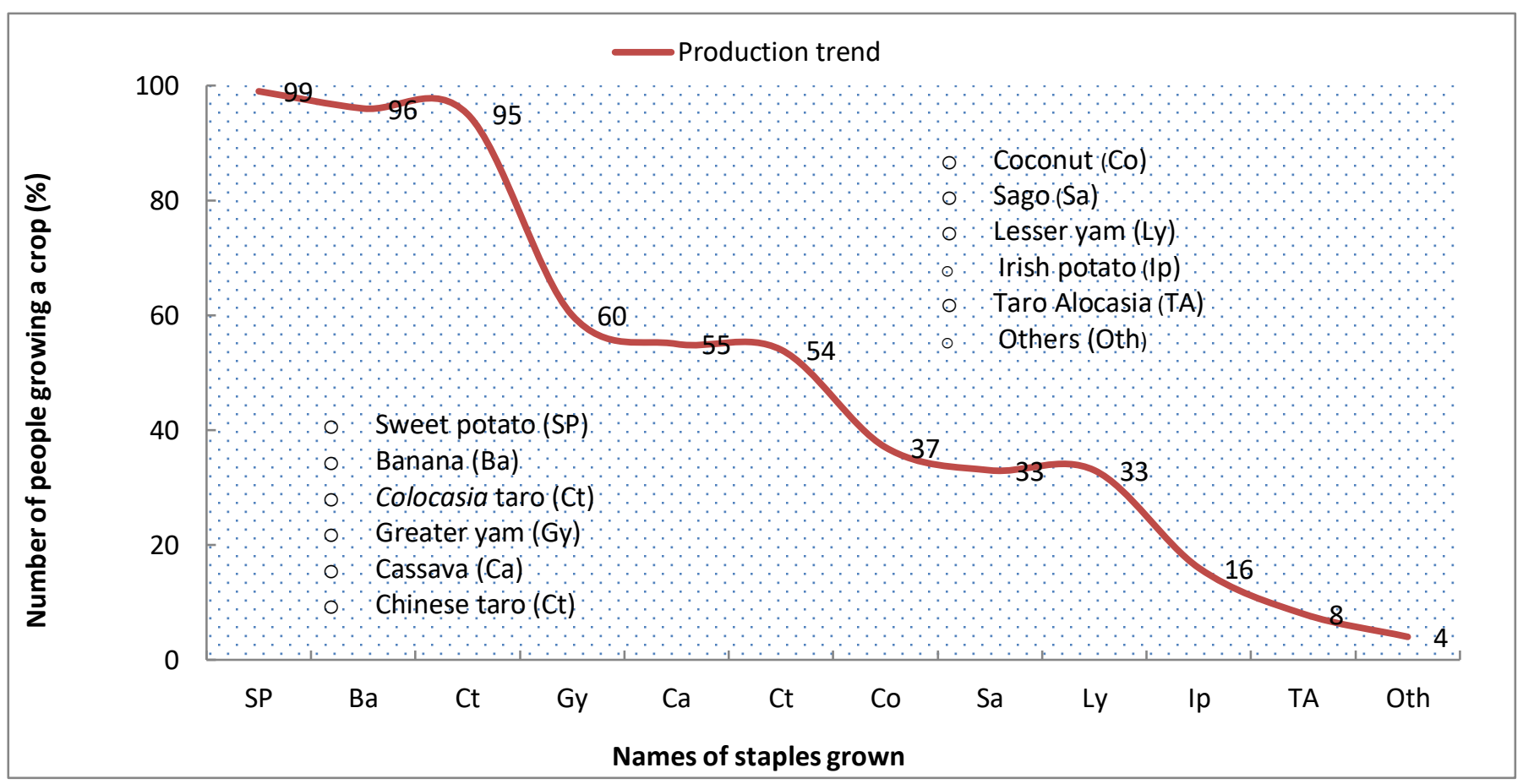

Figure 9. Number of people growing the staples (Bourke \& Allen, 2009).

\section{Agriculture Development}

In the next 80 years (2020-2100), Michael (2019) pointed out that the projected changes in the climate are within the current production ranges (adaptation agro-ecological zones) of the staples. This study showed the population of PNG will be near 22-31 million by 2100 (Figure 4) and will depend on a small staple-based agriculture, for example sweet potato. Very few and almost only three staples, sweet potato, banana, and Colocasia taro feed more than $90 \%$ of the population. The very small numbers of staples feeding the entire nation questions the very survival of PNG as the projected changes in climate occur. Under the light of the projected climate changes and as population pressure sets in, demand for food will increase, making the need to feed more people becoming a common issue (Gedir, Chain, Trey, \& Turnbull, 2015). The need to produce more food will not only become an issue for development but strategic management of the environment for sufficient and sustainable production (Mendelsohn, 2009), which means sufficient amounts need to be produced from limited land. Surely, the staples adapted to agro-ecological zones will be affected as climatic and environmental conditions change. In addition, only a few staples are feeding $50-90 \%$ of the people (Figure 9) with production of some of them already declining. This makes strategic development of the agriculture sector an important agenda for development.

In the rural villages where more than $85 \%$ of the people live, food security except nutritional security is currently not an issue apart from a smaller number of people living in more than 600 small and isolated islands and atolls. These small communities very much depend on food obtained from the sea and small quantity of a particular staple, e.g. cassava, cultivated on fragile land available. These are exuberated by changes in sea level, sea acidification, and saline intrusion including inundation of land used for food production (Costanza et al., 1997). The changes in climate and impacts on livelihoods are disaster for tangible socio-economic development (e.g. Alagidede, Adu, \& Frimpong, 2016; Fankhauser \& Tol, 2005) in any place. Rise in sea level and saltwater intrusion of land for production is hindrance to agricultural development, complicated by lack of free land availability for relocation of displaced communities (Michael, 2019). Inundation and invasion of lower-lying land are already displacing communities including their religious, cultural, and ritual or other ceremonial including leisure and creational sites (Kulp \& Strauss, 2019).

In the light of the aforementioned and the need to feed extra people, PNG needs to strategically develop the agriculture sector by 2040. In Table 2, the very staples (crops) that are feeding the current population and need further development are shown. A good number of these crops are well adapted to the prevailing agro-climatic conditions and need to be developed to feed the future population. Since the 1600 s and probably earlier to the current times, four root and tuber crops, apart from banana and sago, fed and feed the rural populace, including those in towns and cities. This work pointed out that loss of these narrow staple-based livelihood questions the very survival of the people as climate change affects the ecological and climatic adaptation ranges pointed out earlier.

\subsection{Development of water-loving crops under high rainfall}

Under the influence of climate change, the rainfall pattern and distribution are projected to change, and will have impact on crop production (Kumar, Kumar, Ashrit, Deshpande, \& Hansen, 2004). This means staples like sweet potato and taro will no longer be grown in the regions of adaptation or their production systems need to change (Olesen \& Bindi, 2002). In the event that rainfall increases as projected, sago and Colocasia taro are target crops. Over the last few years, sago 
production has declined despite its wider adaptability (Table 2). Unless the projected increase in temperature leads to severe drought, this crop needs to be promoted as increase in rainfall will create conducive climatic and environmental conditions for increase production. Sago is hardy under excess water and inundation of the lower-lying areas may further favor its production (Townsend, 1974). One of the major approaches to develop this staple is development of plantations for systematic production. Development should include systematic development of plantations, planting, management, and harvesting. A necessary propagation would become handy. Like sago, taro is equally water-loving and important starchy crop (Dapaah, 1994; Pe, Netondo, Kataka, \& Palapala, 2015). As at present, this crop is produced on small-scale (Rashmi et al., 2018) and limited to certain provinces in few regions (refer to Figure 8 for the taro producing regions). It is anticipated that increase in rainfall will boost its production (Deo, Tyagi, Taylor, Becker, \& Harding, 2009) throughout the country. Taro is common in high altitude areas as high as 2500 altitude (Figure 6) and the varieties that are adapted there need to be developed further. Currently, on average, 9 tons ha- year $^{-1}$ is produced (Table 2).

The third important water-loving crop that is widely consumed is rice and 2 tons ha ${ }^{-1}$ year $^{-1}$ (Table 2). Globally, rice feeds billions of people and yield can be adequate from a number of hectares of land (Kubo \& Purevdorj, 2004). In PNG, rice consumption is common among working class people and is a talked about crop but development is still an issue. Production of this crop on a wider-scale, possibly by freeing up more customary lands, will feed more than $50 \%$ of the people although need for irrigation may become common when limitations set in (e.g. under elevated temperature). Increased and frequent rainfall would mean introduction of new varieties, and changes in production and management systems (Harvey et al., 2018). Upland rice varieties are currently trialed in many multi-locational trials, and based on that, large-scale production is possible.

\subsection{Development of crops tolerant to elevated temperature}

Most of the staples shown in Table 2 are currently grown under well-drained soil with adequate moisture, unlike sago, taro, and rice discussed above. As places get warmer due to increase in temperature, water-logged and inundated soils may lose water, resulting in availability of land. Taking into consideration soil moisture requirement of crops, cassava is grown by wide range of communities around the globe in places moisture is a total deficit (Brown, Gleadow, \& Miller, 2016). Cassava is the third most important source of calories in the tropics (Montagnac, Davis, \& Tanumihardjo, 2009) and feeds millions of people globally (Balagopalan, 2002). Studies show cassava tolerates temperature range of $16-38^{\circ} \mathrm{C}$ (Alves, 2002; El-Sharkawy, 2003). In PNG, production is limited to a few places (Figure 8) and wider adaption is yet to be realized, with producting averaging 19 tons ha ${ }^{-1}$ year ${ }^{-1}$ (Table 2). In some parts of the country (e.g. in Enga Province in the Highlands Region and parts of Central Province in the Southern Region), occasional drought events occur and prolonged occurrence leads to food crisis. In these places, cassava development is an important food crisis management strategy (Challinor, Wheeler, Garforth, Craufurd, \& Kassam, 2007; Nassar \& Ortiz, 2007). The crop can feed people as well as livestock during food crises and hard times as its production can easily be increased and managed from even a small proportion of land.

Similarly, yam, if widely accepted and cultivated, is significantly important as sweet potato and cassava (Onwueme \& Haverkort, 1991). Yam is well adapted to the Southern region and becoming quite popular in the lower highlands (600-1000 altitude, Figure 6), Momase, and Islands. The crop can be grown within temperature range of $25-30^{\circ} \mathrm{C}$ (Srivastava, Gaiser, Paeth, \& Ewert, 2012), very much within the projected temperature ranges shown in Table 3. The increase in temperature in the cooler highlands will mean warmer climate, suitable for yam production (Regina, Kikuno, \& Maruyama, 2011). Since 1961 to 2017, available data show the production of yam has increased to 363,000 tons (FAOSTAT, 2019). Yam has become a staple diet for many people at the coastal areas and now in the lower highlands (600-1000 altitude), with annual production averaging 15 tons ha ${ }^{-1}$ year $^{-1}$ (Table 2). The increase in altitude for this crop will advance as temperature increases and the cooler mountain areas become warmer.

Table 2. Agro-ecological adaptation of staple crops and need for development

\begin{tabular}{|c|c|c|c|}
\hline Staple & Regional adaptation & Regions for strategic development & $\begin{array}{l}\text { 1Production } \\
\text { (tons ha-1 } \mathrm{yr}^{-1} \text { ) }\end{array}$ \\
\hline Sweet potato & All the regions & Manus, the Sepiks and others & 14 (all regions) \\
\hline Cassava & All the regions & In most of the regions & 19 (all regions) \\
\hline Irish potato & Highlands, Momase* & Highlands, Momase & 14 (only highlands) \\
\hline Taro & Momase, NGI & Highlands and Southern regions & 9 (all regions) \\
\hline Yam & Southern & Momase, Highlands, NGI & 15 (only lowlands**) \\
\hline Banana & Momase*, Southern* & In most of the regions & 10.5 (all regions) \\
\hline Sago & Southern*, Momase* & In most of the regions & $\mathrm{N} / \mathrm{A}$ \\
\hline Rice & All the regions & In most of the regions & 2 (only lowlands) \\
\hline Wheat & Highlands & Highlands region & $\mathrm{N} / \mathrm{A}$ \\
\hline
\end{tabular}

* Denotes a staple is partly adapted to a region. ${ }^{* *}$ The lowland is inclusive of Momase, Southern and Islands regions, respectively. N/A is production data not available. ${ }^{1}$ From Bourke \& Vlassak (2004). 
Table 3. Projected temperature changes in PNG between 2040 and 2100 (Michael, 2019)

\begin{tabular}{llllll}
\hline ACZ & Altitude & $\mathbf{2 0 4 0}$ & $\mathbf{2 0 6 0}$ & $\mathbf{2 0 8 0}$ & $\mathbf{2 1 0 0}$ \\
\hline 1 & $0-600$ & $28.6-29.4$ & $28.8-29.6$ & $29.0-29.8$ & $29.2-30.0$ \\
2 & $600-1500$ & $26.4-27.4$ & $26.8-27.6$ & $27.0-27.8$ & $27.2-28.0$ \\
3 & $1500->2500$ & $23.6-24.4$ & $23.8-24.6$ & $24.0-24.8$ & $24.2-25.0$ \\
\hline
\end{tabular}

ACZ is agro-climatic zones, $1=$ Coastal, $2=$ Inland and $3=$ mountain (cooler) areas, respectively

In the highlands, Irish potato (Solanum tuberosum) is grown from between 700-3000 altitude, and production is nearly below $20 \%$ with annual production on average 14 tonnes ha ${ }^{-1}$ year $^{-1}$ (Table 2), mostly from subsistence farmers. Potato is a cool climate crop within temperature range of 15$20^{\circ} \mathrm{C}$ (Bourke \& Allen, 2009), and production would be a problem under high temperature. This crop is widely consumed and demand for it will increase as need for more food becomes common. The current production areas in the cooler mountain areas are within $20-22^{\circ} \mathrm{C}$ and projected increase by near $2-4^{\circ} \mathrm{C}$ by 2100 (IPCC, 2007) means reduction in yield. Global production of potato is even already projected to decline by $18-32 \%$ by 2020 (Hancock et al., 2013). In most homes, potato is unable to meet the calorie requirement of households, therefore consumed in combination with one or two other staples, e.g. sweet potato or banana.

There is a great potential for large-scale banana (Musa sp.) production and quite popular with the people, with production averaging 11 tons ha ${ }^{-1}$ year $^{-1}$ (Table 2). Large varieties of banana are found in PNG but production on larger-scale is limited to Morobe in Momase and Central in Southern region (Figure 8), respectively. In many areas, banana is planted in smaller plantations own by family units for own consumption. This crop is an underutilized fruit crop (Padam, Tin, Chye, \& Abdullah, 2014) and can become an important crop as climate change becomes more pronounced. The average temperature requirement for the crop is around $27^{\circ} \mathrm{C}$ (Varma \& Bebber, 2019) and an annual increase will boost production in the tropics (CGIAR, 2015). In all the regions, increase in production of this crop will become important as the changes in global temperature projection will be within the current production ranges. In most of the regions, the crop is solely consumed for a meal, indicating its production alone is significant to the people.

Wheat is widely grown in the world and by 2050 it is expected to feed 9.2 billion people (Strugnell, 2018). In PNG, the crop's adaptation regions are yet to be established but trialed out at the high altitude areas in Kandep in Enga Province and Tambul in the Western Highlands Province, respectively. Like rice, this crop will become a strategic crop for mitigating climate change and addressing food security, although yield and nutrition are unpredictable (Myers, Zanobetti, Kloog, Huybers, \& et al., 2014; Shewry \& Hey, 2015). Assessment of wheat production under climate change shows that unless steps are taken, $60 \%$ of the current wheatgrowing areas will face severe drought, resulting in decline in production (Trnka et al., 2019). Whilst the current production areas face severe drought within the next $40-80$ years, increase in rainfall is projected for PNG, pointing out rain-fed production will benefit development. In addition to rice, all major cereals (maize and sorghum) will become prominent in the agriculture sector, not only as food but as feed for livestock production.

\section{Agriculture development implications}

In crop agriculture, climatic and environmental factors (soil nutrients, water availability, irradiation, and $\mathrm{CO}_{2}$ concentrations) and farming systems are important for production and management. In the subsistence food gardens where mixing farming is practiced for production of the staples, fertilizer application is not common. Land pressure is common in most places because of limited land availability (1,190 ha) and the need for continuous production to feed increase in population. In some places, for example, Simbu in the highlands, high population density is already putting pressure on the limited land that is available, in part, due to topographic (e.g. hilly and steep landscape) difficulties of the province. When the population density increases to 42 per $\mathrm{km}^{2}$ in 2095 compared to 20 people per $\mathrm{km}^{2}$ now, pressure on available land ( $97 \%$ customary and $3 \%$ alienated) will be experienced in all the regions, particularly in the highlands were the population will be near 14 million people by 2100 (Figure 3 ). In the regions, the population densities will be in the order 80 (highlands of $62,400 \mathrm{~km}^{2}$ ), 21 (Islands of $56,472 \mathrm{~km}^{2}$ ), 16 (Momase of 142, $311 \mathrm{~km}^{2}$ ) and 7 (Southern of $202,542 \mathrm{~km}^{2}$ ) people per $\mathrm{km}^{2}$ within the same period.

In the village farming systems (e.g. slash-and-burn and mixed farming), most farmers practice sustainable techniques like legume rotation but with limited vegetable legumes like beans and peas because of obvious cash and food benefits. Therefore, in most regions, soil fertility in subsistence farms is sustained by the mixed farming system. In almost all subsistence farms, the economical products are harvested and taken, however, a lot of crop wastes (plant materials) from a range of food crops are left on the farm, which then become available to the soil as organic matter. Decomposition of these varieties of plant material is the sole reason why soil fertility is sustainably high in subsistence farming system where fertilizer application is not a common practice. Some of the reasons for non-availability include remoteness, costs associated with purchase or transportation being relatively expensive. In addition to that, staples cultivated are adapted to local conditions and not "hungry crops". The cropland is fallowed for a short period of time, e.g. 1-3 years, before tilling again, which helps revert the soils in terms of important soil characteristics. Increase in population density and changes in global climate may lead to shortened period of fallow, leading to decrease in soil fertility status and urge for the need of chemical fertilizers.

Crop production in PNG is rainfed and irrigation is not required unless there is drought or severe water shortage as a result of land use or following a natural catastrophic event, like drought. In addition, most of the regions are projected to receive increase in rainfall within the next $70-80$ years (Michael, 2019), which is by 2090-2100. This demonstrates rainfall will not be an issue for crop production except that 
the excess moisture would become a limitation for some staple, like sweet potato whilst water loving crops such as taro will enjoy it. As the projection shows, most of the provinces in the regions will receive rainfall from $260 \mathrm{~cm}$ to $280 \mathrm{~cm}$ or even greater (Michael, 2019). Increase in rainfall would mean decline in production of staples like sweet potato, e.g. in the highlands. That could mean need for introduction of water-loving crops or just introduction of new varieties. Production of staples under climate change or introducing new varieties would mean more challenges for production and management (Parry, 1998).

Crop such as potato, for example, is hardly grown without application of pesticide or fungicide. Increase in rainfall would mean changes in production system. The rise in temperature will further affect the water-loving crops pointed out earlier, just like the counterparts that need reasonable amounts for normal growth. The amount and quality of water that will be available in different regions will determine sustainable staple production. In the highlands, for example, increase in rainfall could mean heavy floods and landslides, compromising the quality of water available. Rest of the regions are located near the coast, which means saltwater intrusion and salinity rise as a result of flood events and rise in sea level will become common (Michael, 2019). Water quality will off course become compromised because of saltwater intrusion and rise in salinity and decomposition of dead organisms as a result of inundation. All of these are potent source of water-borne pests and diseases to all plants and animals.

Carbon dioxide is needed by plants for photosynthesis but how much is needed is dependent on plant types and the climatic and environmental conditions. Under climate change, atmospheric $\mathrm{CO}_{2}$ concentration is projected to rise and expected to have varying effects on different crops. Most of the staples (Figure 8) are $\mathrm{C}_{3}$ and depend on the available atmospheric concentration (Michael, 2019). High atmospheric concentrations of $\mathrm{CO}_{2}$ have fertilizing effects on $\mathrm{C}_{3}$ plants. Increase in temperature followed by drought events significantly affects $C_{3}$ staples and this will be a disaster for the people. Under high temperature and limited water availability of low stomatal conductance, $\mathrm{C}_{4}$ plants maintain $\mathrm{CO}_{2}$ assimilation (Knapp \& Medina, 1999). On the other land, $\mathrm{C}_{3}$ staples have water use efficiency advantage because increase in $\mathrm{CO}_{2}$ means reduced transpiration rates and increased in $\mathrm{CO}_{2}$ assimilation. In the event drought becomes a problem, the need for introducing more $\mathrm{C}_{4}$ crops will be the challenge for development on the plant agriculture sector.

Studies show global warming could result in increase in number and appetite of insects. Under high temperature, metabolic rates of insets increase and make them to consume more (Irlich, Terblanche, Blackburn, \& Chown, 2009). The population of insects is dependent on temperature and may result in outbreaks, though a study indicated growth rates may be lower in the tropics than elsewhere (Deutsch et al., 2008). One study showed an increase in insect pests will result in yield loss of wheat, rice, and maize by $46 \%, 19 \%$, and $31 \%$ (Deutsch et al., 2018), respectively. Most of the categories of weeds in the tropics are either $C_{3}$ or $C_{4}$ plants and changes in $\mathrm{CO}_{2}$ will affect their productivity. Just like the $\mathrm{C}_{3}$ staples, $\mathrm{C}_{3}$ weeds will enjoy the increase in atmospheric $\mathrm{CO}_{2}$ and increase biomass production, resulting in enhanced competition with crops. As pointed out previously, the fertilizing effect of high $\mathrm{CO}_{2}$ makes $\mathrm{C}_{4}$ weeds to reduce water stress and enhance growth, making them to become problematic under water stress (high temperature) conditions like their $C_{3}$ counterparts under adequate moisture (Michael, 2019). Such changes will not only disadvantage the rural farmers but question local pests and disease control methods or traditional knowledge on management.

A growing number of literatures point out that as global climate changes, crop diseases will become more severe, epidemic, and frequent and spread to other areas as the climatic and environmental barriers break down (e.g. Ahanger et al., 2013; Ladanyi \& Horvath, 2010; Runion, 2003). These will threaten production and management systems of crops; bring frequency of production to a whole new level, never practiced before (Parry, 1998). Disease spread and development are affected by crop nutrients, which are indirectly affected by the climate (Walters \& Bingham, 2007). Important nutrients becoming deficient under a new climate could lead to ill-health of crops (poor growth) and make them vulnerable to disease attacks as their defense weakens (Goodman \& Newton, 2005). Crops ability to withstand abiotic and biotic stresses is either resilience or resistance (Kissoudis, van de Wiel, Visser, \& van der Linden, 2014). Most staples cultivated are generally selected for a particular trait and mostly not protected like in monoculture plantations, e.g. through fertilizer management or a pest control program. These scenarios make the staples seriously vulnerable to all types of stresses under climate change.

The staples (shown in Figure 8) are mostly root and tuber crops and contain a lot of water, making them susceptible to damages and infections at all levels of production, from field to harvesting and post-harvest handling. Unlike in monoculture plantations where biological agents are scolded by chemicals, pests, and disease buildups in the village mixed farms are put under check by beneficial biological agents that co-evolved with the local conditions of staple production. As climate stresses set in, some of them will disappear completely, making the need to control pests (insects and weeds) and disease causing pathogens to become widespread. The opposite is true, the pests and disease causing pathogens need to adapt to changes themselves to survive as pests, otherwise, extinction or change in pest status is possible (Gioria \& Osborne, 2014). There is possibility too that surge in new pests and disease causing organisms not known may occur, however, the question is, will they become pests under the altered climate for the current staples. It is unlikely, the new pest or organism will become an immediate pest or pathogen, based on the fact that an insect with pest status is an evolutionary trait, and so is the pest-crop relationship that exists (Dar et al., 2019). The new crop of pests and pathogens will need to fend for a while, develop the host-pathogen relationship against "invasional meltdown" before reaching the pests or pathogen status of a crop (Kulmatiski, 2006). The altered climate may not be even conducive at all for the new pests and pathogens to survive (Gioria \& Osborne, 2014), forcing them to die out. 


\section{Conclusion}

Global climate change has already hit the planet and its impacts are compounded by the pressure of increasing populations, adding to limited resource availability. Current projections show the world population will be 9 billion by 2100. The ever increasing population needs to be fed and the only practice that does that on earth is agriculture. Sustainable production of food from this practice entirely depends on climatic and environmental factors that are changing because of climate change. These are challenging the current levels of interactions of the people towards the environment in the quest to mitigate, become resilient, and adapt to the impacts of climate change and increase in population. In the light of all of these, people need to understand what their population sizes will be and how the people will be fed. This study showed within the next 80 years (2020-2100), the population of PNG will be near 31 million people however will be fed from a very narrow staple-based agriculture, most of which are root and tuber crops. Under climate change, this narrow staple-based agriculture questions the very survival of PNG and efforts needed to divert to addressing food security starting within the next 20 years. This work showed climate change will challenge agriculture to a limit where productivity of staples will no longer be sustainable as climatic and environmental factors (e.g. soil nutrients, soil moisture, temperature, rainfall, and irradiation including $\mathrm{CO}_{2}$ levels) adapted get altered. All efforts of mitigation, resilience, and adaptation to climate change to provide food under altered adapted climatic and environmental conditions is humanity's hardest struggle for survival. In many regions, crop production and management systems are developed and adapted to suit varied local climate, therefore, need for new systems under the altered climate. Though the context of this work is PNG, it points out a greater need for evaluating location-specific staples that feed the local people in the light of climate change and has wider implications, worldwide.

\section{Acknowledgement}

There is no conflict of interest related to this work. Literatures on PNG climate were collated by Malice Michael, Alice Pokon, Jessica Aipa, Pamawi Meko Michael, and Wentu Ezekiel Michael under my guidance. Their skills in literature collection were speedier than I thought which helped in the structure and organization of this work. The anonymous reviewers whose input improved the quality of the manuscript are acknowledged.

\section{Declaration of Competing Interest}

The authors declare no competing financial or personal interests that may appear and influence the work reported in this paper.

\section{References}

Ahanger, R. A., Bhat, H. A., Bhat, T. A., Ganie, S. A., Lone, A. A., Wani, I. A., ... Bhat, T. A. (2013). Impact of climate change on plant diseases. International Journal of
Modern Plant and Animal Sciences, 1(13), 105-115.

Alagidede, P., Adu, G., \& Frimpong, P. B. (2016). The effect of climate change on economic growth: evidence from Sub-Saharan Africa. Environmental Economics and Policy Studies, 18, 417-436. https://doi.org/10.1007/s10018-015-0116-3

Allen, B. J., Bourke, R. M., \& Hanson, L. (2001). Dimensions of Papua New Guinea village agriculture. In R. M. Bourke, M. G. Allen, \& J. G. Salisbury (Eds.), Food Security for Papua New Guinea. Proceedings of the Papua New Guinea Food and Nutrition 2000 Conference. ACIAR Proceedings No 99 (pp. 529-553). Canberra, Australia: Australian Centre for International Agricultural Research.

Alves, A. A. C. (2002). Cassava botany and physiology. In R. J. Hillocks, J. M. Thresh, \& A. C. Bellotti (Eds.), Cassava: Biology, production and utilization (pp. 67-89). Oxon, UK: CABI Publishing.

Balagopalan, C. (2002). Cassava utilization in food, feed and Industry. In R. J. Hillocks, J. M. Thresh, \& A. C. Bellotti (Eds.), Cassava: Biology, production and utilization (pp. 301-318). Oxon, UK: CABI Publishing.

Battisti, D. S., \& Naylor, R. L. (2009). Historical warnings of future food insecurity with unprecedented seasonal heat. Science, 323(5911), 240-244. https://doi.org/10.1126/science.1164363

Bellamy, J. A. (1995). Rainfall erosivity in Papua New Guinea. PNGRIS Publication no. 9. Canberra, Australia: Australian Agency for International Development.

Bellamy, J. A., \& McAlpine, J. R. (1995). Papua New Guinea inventory of natural resources, population distribution and land use handbook. PNGRIS publication no. 6 . Canberra, Australia: Australian Agency for International Development.

Bourke, R. M., \& Allen, R. (2009). Food and agriculture in Papua New Guinea. In R. M. Bourke \& T. Harwood (Eds.), Village food production systems (pp. 194-269). Canberra, Australia: ANU Press.

Bourke, R. M., \& Vlassak, V. (2004). Estimates of food crop production in Papua New Guinea. Canberra, Australia: Land Management Group, Research School of Asia and the Pacific, The Australian National University.

Brown, A. L., Gleadow, R., \& Miller, R. E. (2016). Interactive effects of temperature and drought on cassava growth and toxicity: implications for food security? Global Change Biology, 22(10), 3461-3473. https://doi.org/10.1111/gcb.13380

CGIAR (Consultative Group for International Agriculture Research). (2015). Bananas and climate change: what is going to happen to one of the world's favorite fruits? Retrieved March 3, 2020, from https://www.bioversityinternational.org/news/detail/ bananas-and-climate-change-what-is-going-tohappen-to-one-of-the-worlds-favourite-fruits/

Challinor, A., Wheeler, T., Garforth, C., Craufurd, P., \& Kassam, A. (2007). Assessing the vulnerability of food crop systems in Africa to climate change. Climatic Change, 83, 381-399. https://doi.org/10.1007/s10584007-9249-0 
Costanza, R., D’Arge, R., de Groot, R., Farber, S., Grasso, M., \& et al. (1997). The value of the world's ecosystem services and natural capital. Nature, 387, 253-260. https://doi.org/10.1038/387253a0

Dapaah, S. K. (1994). Contributions of root and tuber crops to socioeconomic changes in the development world: The case of Africa, with special emphasis on Ghana. Acta Horticulturae, 380, 44-49. https://doi.org/10.17660/ActaHortic.1994.380.3

Dar, J. A., Subashree, K., Sundarapandian, S., Saikia, P., Kumar, A., Khare, P. K., Dayanandan, S., \& Khan, M. L. (2019). Invasive species and their impact on tropical forests of Central India: A review. In S. Garkoti, S. Van-Bloem, P. Fulé, \& R. Semwal (Eds.), Tropical ecosystems: Structure, functions and challenges in the face of global change (pp. 69-109). Singapore: Springer.

Deo, P. C., Tyagi, A. P., Taylor, M., Becker, D. K., \& Harding, R. M. (2009). Improving taro (Colocasia esculenta var. esculenta) production using biotechnological approaches. The South Pacific Journal of Natural and Applied Sciences, 27(1), 6-13. https://doi.org/10.1071/SP09002

Deutsch, C. A., Tewksbury, J. J., Huey, R. B., Sheldon, K. S., Ghalambor, C. K., Haak, D. C., \& Martin, P. R. (2008). Impact of climate warming on terrestrial ectotherms across latitude. Proceedings of the National Academy of Sciences of the United States of America, 105(18), 6668-6672. https://doi.org/10.1073/pnas.0709472105

Deutsch, C. A., Tewksbury, J. J., Tigchelaar, M., Battisti, D. S., Merrill, S. C., Huey, R. B., \& Naylor, R. L. (2018). Increase in crop losses to insect pests in a warming climate. Science, 361(6405), 916-919. https://doi.org/10.1126/science.aat3466

El-Sharkawy, M. A. (2003). Cassava biology and physiology. Plant Molecular Biology, 53, 621-641. https://doi.org/10.1023/B:PLAN.0000019109.01740.c6

Fankhauser, S., \& Tol, R. S. J. (2005). On climate change and economic growth. Resource and Energy Economic, 27(1), 1-17. https://doi.org/10.1016/j.reseneeco.2004.03.003

FAOSTAT. (2019). Food and Agriculture Data of Papua New Guinea. Retrieved March 2, 2020, from http://www.fao.org/countryprofiles/index/en/?iso3=P NG

Gedir, J. V., Chain, J. W., Trey, H. G., \& Turnbull, T. T. (2015). Effects of climate change on long-term population growth of pronghorn in an arid environment. Ecosphere, 6(10), 1-20. https://doi.org/10.1890/ES1500266.1

Gioria, M., \& Osborne, B. A. (2014). Resource competition in plant invasions: emerging patterns and research needs. Frontiers in Plant Science, 5(501). https://doi.org/10.3389/fpls.2014.00501

Goodman, B. A., \& Newton, A. C. (2005). Effects of drought stress and its sudden relief on free radical processes in barley. Journal of the Science of Food and Agriculture, 85(1), 47-53. https://doi.org/10.1002/jsfa.1938

Gornall, J., Betts, R., Burke, E., Clark, R., Camp, J., Willett, K., \& Wiltshire, A. (2010). Implications of climate change for agricultural productivity in the early twenty-first century. Philosophical Transactions of the Royal Society B, 365(1554), 2973-2989. https://doi.org/10.1098/rstb.2010.0158

Hancock, R. D., Morris, W. L., Ducreux, L. J. M., Morris, J. A., Usman, M., Verrall, S. R., ... Taylor, M. A. (2013). Physiological, biochemical and molecular responses of the potato (Solanum tuberosum L.) plant to moderately elevated temperature. Plant Cell and Environment, 37(2), 439-50. https://doi.org/10.1111/pce.12168

Harvey, C. A., Saborio-Rodríguez, M., Martinez-Rodríguez, M. R., Viguera, B., Chain-Guadarrama, A., Vignola, R., \& Alpizar, F. (2018). Climate change impacts and adaptation among smallholder farmers in Central America. Agriculture \& Food Security, 7(57). https://doi.org/10.1186/s40066-018-0209-x

Hussain, M. S., \& Javadi, A. A. (2016). Assessing impacts of sea level rise on seawater intrusion in a coastal aquifer with sloped shoreline boundary. Journal of HydroEnvironment Research, 11, 29-41. https://doi.org/10.1016/j.jher.2016.01.003

IPCC. (1990). Climate change: The IPCC scientific assessment. In J. T. Houghton, G. J. Jenkins, \& J. J. Ephraums (Eds.), World meteorological organization and United Nations environmental program (p. 365p.). Cambridge, UK: Cambridge University Press.

IPCC. (2007). IPCC fourth assessment report 2007. Working group II report impacts, adaptation and vulnerability. Retrieved March 5, 2020, from http://www.ipccwg2.org

IPCC. (2013). Climate Change 2013: The Physical Science Basis. Contribution of Working Group I to the Fifth Assessment Report of the Intergovernmental Panel on Climate Change. (S. T.F., D. Qin, G.-K. Plattner, M. Tignor, S. K. Allen, J. Boschung, ... P. M. Midgley, Eds.). Cambridge, UK and New York, USA: Cambridge University Press.

Irlich, U., Terblanche, J. S., Blackburn, T. M., \& Chown, S. L. (2009). Insect rate-temperature relationships: Environmental variation and the metabolic theory of ecology. The American Naturalist, 174(6), 819-835. https://doi.org/10.2307/27735897

Kissoudis, C., van de Wiel, C., Visser, R. G. F., \& van der Linden, G. (2014). Enhancing crop resilience to combined abiotic and biotic stress through the dissection of physiological and molecular crosstalk. Frontiers in Plant Science, 5(207), 1-20. https://doi.org/10.3389/fpls.2014.00207

Knapp, A. K., \& Medina, E. (1999). Success of C4 photosynthesis in the field: lessons from communities dominated by C4 plants. In R. F. Sage \& R. K. Monson (Eds.), Plant Biology (pp. 251-283). London, UK: Academic Press.

Knoema. (2018). Papua New Guinea CO2 emissions, 19702018. Retrieved February 3, 2020, from https://knoema.com/atlas/Papua-New-Guinea/CO2emissions-per-capita

Kostrowicki, J. (1983). Land use systems and their impact on environment. An attempt at a classification. Advances 
in Space Research, 2(8), 209-215. https://doi.org/10.1016/0273-1177(82)90242-3

Kubo, M., \& Purevdorj, M. (2004). The future of rice production and consumption. Journal of Food Distribution Research, 35(1), 1-15. https://doi.org/10.22004/ag.econ.27145

Kulmatiski, A. (2006). Exotic plants establish persistent communities. Plant Ecology, 187, 261-275. https://doi.org/10.1007/s11258-006-9140-5

Kulp, S. A., \& Strauss, B. H. (2019). New elevation data triple estimates of global vulnerability to sea-level rise and coastal flooding. Nature Communication, 10(4844).

Kumar, K. K., Kumar, K. R., Ashrit, R. G., Deshpande, N. R., \& Hansen, J. W. (2004). Climate impacts on Indian agriculture. International Journal of Climatology, 24, 1375-1393. https://doi.org/10.1002/joc.1081

Ladanyi, M., \& Horvath, L. (2010). A review of the potential climate change impact on insect populations - general and agricultural aspects. Applied Ecology and Environmental Research, 8(2), 143-152.

Lu, C., \& Werner, A. D. (2013). Timescales of seawater intrusion and retreat. Advances in Water Resources, 59, 39-51.

https://doi.org/10.1016/j.advwatres.2013.05.005

Mcalpine, J., Keig, G., \& Short, K. (1975). Climatic tables for Papua New Guinea. Technical Paper No. 37. Canberra, Australia.

Mendelsohn, R. (2009). The impact of climate change on agriculture in developing countries. Journal of Natural Resources Policy Research, 1(1), 5-19. https://doi.org/10.1080/19390450802495882

Michael, P. S. (2019). Current evidence and future projections: a comparative analysis of the impacts of climate change on critical climate-sensitive areas of Papua New Guinea. SAINS TANAH - Journal of Soil Science and Agroclimatology, 16(2), 229-253. https://doi.org/10.20961/stjssa.v16i2.35712

Michael, P. S., Fitzpatrick, W. R., \& Reid, J. R. (2017). Effects of live wetland plant macrophytes on acidification, redox potential and sulfate content in acid sulphate soils. Soil Use and Management, 33(3), 471-481. https://doi.org/10.1111/sum.12362

Michael, P. S., \& Reid, J. R. (2018). The combined effects of complex organic matter and plants on the chemistry of acid sulfate soils under aerobic and anaerobic soil conditions. Journal of Soil Science and Plant Nutrition, 18, 542-555.

Montagnac, J. A., Davis, C. R., \& Tanumihardjo, S. A. (2009). Nutritional value of cassava for use as a staple food and recent advances for improvement. Comprehensive Reviews in Food Science and Food Safety, 8(3), 181-194. https://doi.org/10.1111/j.1541-4337.2009.00077.x

Myers, S. S., Zanobetti, A., Kloog, I., Huybers, P., \& et al. (2014). Increasing CO2 threatens human nutrition. Nature, 510, pages139-142. https://doi.org/10.1038/nature13179

Nassar, N. M. A., \& Ortiz, R. (2007). Cassava improvement: Challenges and impacts. The Journal of Agriculture Science, 145(2), 163-171.
https://doi.org/10.1017/S0021859606006575

Nix, H. A. (1985). Climate Impact Assessment. In R. W. Kates, J. H. Ausubel, \& M. Berberian (Eds.), SCOPE 27. New York, USA: Wiley.

Olesen, J. E., \& Bindi, M. (2002). Consequences of climate change for European agricultural productivity, land use and policy. European Journal of Agronomy, 16(4), 239262. https://doi.org/10.1016/S1161-0301(02)00004-7

Onwueme, I. C., \& Haverkort, A. J. (1991). Modelling growth and productivity of yams (Dioscorea spp.): prospects and problems. Agricltural System, 31(3), 351-367. https://doi.org/10.1016/0308-521X(91)90015-3

Padam, B. S., Tin, H. S., Chye, F. Y., \& Abdullah, M. I. (2014). Banana by-products: an under-utilized renewable food biomass with feat potential. Journal of Food Science and Technology, 51(12), 3527-3545. https://doi.org/10.1007/s13197-012-0861-2

Parry, M. L. (1998). The impact of climate change on European agriculture. In T. Lewis (Ed.), The Bawden Memorial Lectures 1973-1998 (Silver Jub, pp. 325-338). Farnham, UK: British Crop Protection Council.

Pe, A., Netondo, G., Kataka, J. A., \& Palapala, V. A. (2015). A critical review of the role of taro Colocasia esculenta $L$. (Schott) to food security: A comparative analysis of Kenya and Pacific Island taro germplasm. Scientia Agriculturae, 9(2), 101-108.

Peel, C., Finlayson, B. L., \& McMahon, T. A. (2007). Updated world map of the Köppen-Geiger climate classification. Hydrology and Earth System Sciences, 11, 1633-1644. https://doi.org/10.5194/hess-11-1633-2007

PNG NSO. (2011). National population and housing census 2011. Retrieved March 19, 2020, from https://www.nso.gov.pg/

Pretty, J. (1999). Can sustainable agriculture feed Africa? New evidence on progress, processes and impacts. Environment, Development and Sustainability, 1, 253274.

Rashmi, D. R., Anitha, B., Anjum, S. R., Raghu, N., Gopenath, T. S., Chandrashekrappa, G. K., \& Kanthesh, M. B. (2018). An overview of taro (Colocasia esculenta): A review. Academia Journal of Agricultural Research, 6(10), 346-353. https://doi.org/10.15413/ajar.2018.0144

Regina, H. Y. F., Kikuno, H., \& Maruyama, M. (2011). Research on yam production, marketing and consumption of Nupe farmers of Niger State, central Nigeria. African Journal of Agricultural Research, 6(23), 5301-5313. https://doi.org/10.5897/AJAR11.586

Runion, G. B. (2003). Climate change and plant pathosystems: Future disease prevention starts here. New Phytologist, 159(3), 531-533. https://doi.org/10.1046/j.14698137.2003.00868.x

Selassie, Y. G., Anemut, F., \& Addisu, S. (2015). The effects of land use types, management practices and slope classes on selected soil physico-chemical properties in Zikre watershed, North-Western Ethiopia. Environmental Systems Research, 4(3). https://doi.org/10.1186/s40068-015-0027-0

Sherif, M., \& Singh, V. P. (1999). Effect of climate change on 
sea water intrusion in coastal aquifers. Hydrological Processes, 13(8), 1277-1287.

Shewry, P. R., \& Hey, S. J. (2015). The contribution of wheat to human diet and health. Food and Energy Security, 4, $178-202$.

Srivastava, A. K., Gaiser, T., Paeth, H., \& Ewert, F. (2012). The impact of climate change on yam (Dioscorea alata) yield in the savanna zone of West Africa. Agriculture, Ecosystems and Environment, 153, 57-64.

Strugnell, L. (2018). The importance of wheat in the global food supply to a growing population. Retrieved March 2, 2020, from

https://www.cimmyt.org/publications/newpublications-the-importance-of-wheat-in-the-globalfood-supply-to-a-growing-population/

Thompson, L. M. (1975). Weather variability, climate change and food production. Science, 188, 534-541.

Townsend, P. K. (1974). Sago production in a New Guinea economy. Human Ecology, 2(3), 217-236.

Trnka, M., Feng, S., Semenov, M. A., Olesen, J. E., Kersebaum,
K. C., Rötter, R. P., ... Büntgen, U. (2019). Mitigation efforts will not fully alleviate the increase in water scarcity occurrence probability in wheat-producing areas. Science Advances, 5(9), eaau2406. https://doi.org/10.1126/sciadv.aau2406

United Nations. (2019). World population prospects 2019. Retrieved February 1, 2020, from https://population.un.org/wpp/

Varma, V., \& Bebber, D. P. (2019). Climate change impacts on banana yields around the world. Nature Climate Change Volume, 9, 752-757.

Walters, D. R., \& Bingham, I. J. (2007). Influence of nutrients on disease development caused by fungal pathogens: implications for plant disease control. Annals of Applied Biology, 151(3), 307-324. https://doi.org/10.1111/j.1744-7348.2007.00176.x

Yebo, B. (2015). Integrated soil fertility management for better crop production in Ethiopia. International Journal of Soil Science, 10(1), 1-16. https://doi.org/10.3923/ijss.2015.1.16 